\title{
Pandalid Shrimp as Indicators of Ecosystem Regime Shift
}

\author{
Paul J. Anderson \\ National Marine Fisheries Service, Alaska Fisheries Science Center \\ Kodiak Laboratory, 301 Research Court, Kodiak, Alaska 99615-7400, USA
}

\begin{abstract}
Pandalid shrimp are important components of the cold-regime boreal marine ecosystem in the Gulf of Alaska. Declines in abundance of several pandalid species occurred quickly after 1977 when an abrupt climate change caused water column warming. Shrimp trawl surveys conducted from 1953 to 1999 were used to describe how species composition changed relative to environmental parameters. Proportions of shrimp in survey catches were found to be negatively correlated $(r=-0.72)$ with the water column temperature anomaly. Pandalid shrimp species which occupied inshore and typically shallower water declined to near extinction, while offshore and deep-water shrimp species maintained low population levels. Possible mechanisms responsible for this decline and their replacement by other species are discussed. Climate change as manifested by changes in water column temperature has an immediate effect on lower trophic levels of boreal marine ecosystems and rapid pandalid shrimp population changes are one of the first indicators that a community regime shift is underway.
\end{abstract}

Key words: Climate change, Gulf of Alaska, Indicator species, Pandalid shrimp, Pandalopsis dispar, Pandalus borealis, Pandalus goniurus, Pandalus hysinotus.

\section{Introduction}

It is difficult (if not impossible) to measure the complete set of factors that defines the state of an ecosystem. Indicator species may provide a sense of an ecosystem's status in some global way. The population status of such species may be indicative of environmental changes (Olson and Burgess, 1967) or be correlated with concurrent changes in other species (Thorson, 1957; Dufrêne and Legendre, 1997). Pandalid shrimp occupy a central position in the trophic structure of the northeast Pacific where they constitute the main prey of many fish species and in turn prey on the zooplankton community. They also occupy all depths of the water column from the benthos to near surface. Consequently, changes in their population dynamics may reflect changes occurring within other trophic levels throughout the water column. The decline in several species of pandalids and other changes in the community structure of the Gulf of Alaska (GOA) ecosystem after 1977 has been attributed to climateinduced changes in water column temperatures (Piatt and Anderson, 1996; Anderson and Piatt, 1999). The purpose of this paper is to demonstrate the potential importance of pandalid shrimp as indicator species in the cold regime community structure of the GOA ecosystem.
The GOA is known to alternate between cold and warm climatic regimes lasting from one to three decades before reversal. Climatic data indicate that these two regimes have oscillated at an average frequency of 15 years since 1500 A.D with the longest warm and cold period lasting 34 and 26 years, respectively (Wiles et al., 1998; Ingraham et al., 1998). Perhaps the broadest measure of contemporary climate variability in the GOA is the North Pacific Pressure Index (NPPI) which represents a wide-spread and relatively low frequency climate signal that is related to GOA ocean circulation and temperature (Mantua et al., 1997). In the present study the NPPI and other environmental parameters are used to demonstrate the potential use of pandalid shrimp as early indicators of environmentally induced changes in the GOA marine ecosystem.

Rathbun (1904) first demonstrated the importance of pandalids in the GOA and reported on their distribution from the R/V Albatross (1880) and Harriman Expedition (1899) collections in the northeast Pacific (Harriman, 1910). Eight species of pandalids in two genera represent the largest segment of the near-shore shrimp biomass in the GOA including Pandalus borealis, $P$. goniurus, $P$. hypsinotus, $P$. jordani, P. danae, P. platycerous, $P$. tridens and Pandalopsis 
dispar. Several other deep water and small cryptic pandalid shrimps also occupy the area, but they are not encountered in great numbers.

\section{Methods}

Shrimp and other small-mesh trawl surveys were conducted nearly continuously since 1953 in the GOA. Data from several different agencies were compiled into a single database to represent the period of record. Small-mesh trawl surveys for shrimp conducted by the National Marine Fisheries Service (NMFS) from 195399 and the Alaska Department of Fish and Game (ADF\&G) from 1970-98 comprise most of the data set. The sampling design of these surveys was based on data from early exploratory surveys conducted to locate commercial quantities of shrimp. Over $90 \%$ of survey tows were conducted in May-October. Since early surveys had shown that shrimp concentrated in relatively deep locations in the inshore bays and gullies of the GOA (Ronholt, 1963) most tows were restricted to depths greater than $55 \mathrm{~m}$. After 1971, survey strata were designed for all known major shrimp concentrations in the central and western GOA. Random tow sampling locations within strata were selected for each survey from 1972 to present. Prior to 1972 , tows were conducted with a variety of small- mesh gears having different catch efficiencies. These data are used here to compare relative (\%) catch composition from 1953 to 1997. From 1972 onward, ADF \& G and NMFS standardized methods and used "high-opening" trawls with $32 \mathrm{~mm}$ stretched-mesh throughout (Anderson 1991). Annual catch per unit effort (CPUE), for a given species or group of species, was calculated as total $\mathrm{kg}$ caught divided by total $\mathrm{km}$ trawled. Between 1953 and 1997, 8996 tows covering $17406 \mathrm{~km}$ were conducted (Fig. 1). Annual effort averaged 259 tows year ${ }^{-1}$ (range: $22-775$ ). To examine trends in mean catch biomass only tows (6 812) conducted after 1971 were used. Annual CPUE was compared to within year median $\mathrm{kg} / \mathrm{km}$ to determine the appropriateness of using annual CPUE as a metric of centrality for species abundance. Annual CPUE was used to illustrate biomass trends in all species.

Catches were compared to four available climate indices for the GOA study area: the North Pacific pressure index (NPPI; an index of air pressure at sea level), sea-surface temperatures (SST), GOA air temperatures, and GOA bottom water temperatures. The NPPI index was obtained from S. Hare, Univ. of Washington, Seattle, and is the same as that reported in Mantua et al. (1997). Anomalies from NovemberMarch were normalized, and positive values of the

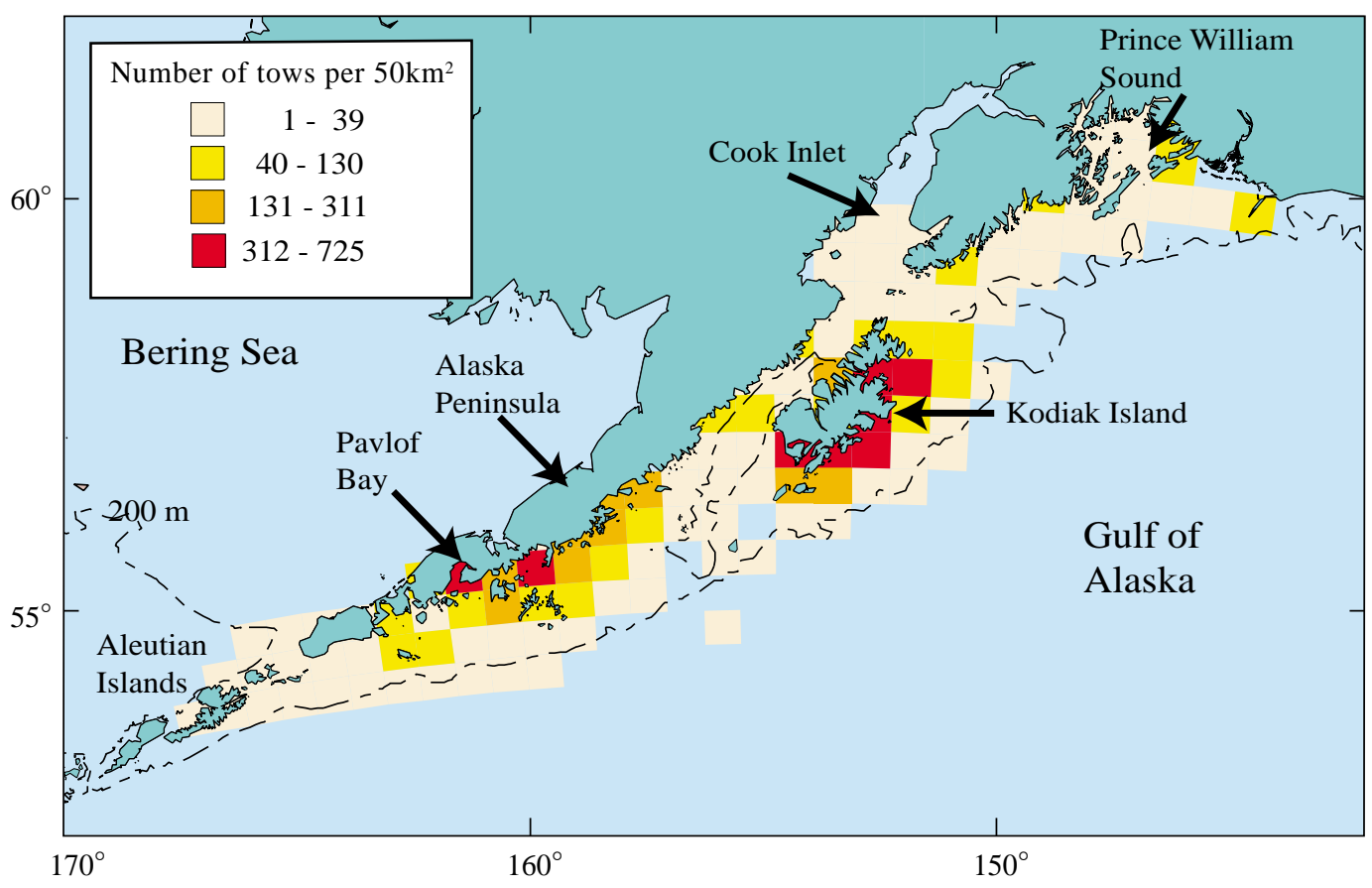

Fig. 1. Major pandalid shrimp fishing areas and distribution of shrimp survey tows $(n=8996)$ in the Gulf of Alaska between 1953 and 1997. 
NPPI correspond to years with a deepened Aleutian Low (Mantua et al., 1997). The NPPI provides an index of large-scale and low frequency climate signals that are widespread and detectable in the North Pacific at interdecadal time scales. Changes in atmospheric pressure patterns in the North Pacific can create persistent blocking ridges that lead to decadal or longer shifts in pressure patterns and storm tracks (Wilson and Overland, 1986). An index of sea level pressure and its concomitant effect on horizontal and vertical mixing through wind stress is probably important in understanding recruitment variability of pandalids with critical larval phases.

Coastal SST time series for British Columbia were obtained from the Institute of Ocean Sciences in Sidney, British Columbia, Canada. No other comparable SST data sets are available for the northern Gulf of Alaska. Normalized anomalies were calculated from a composite of seven widespread coastal observing stations: Amphitrite Point, Race Rocks, Langara Island, Kains Island, McInnes Island, Entrance Island, and Pine Island. This index of nearshore SST was used in an attempt to integrate the wide variation typically seen in areas with diverse topographies like the GOA. It is similar to the index used by Mantua et al. (1997) in their analysis of North Pacific salmon production, but does not include as many sites.

Coastal Gulf of Alaska air temperatures were obtained from the National Climate Data Center. Normalized anomalies shown in Fig. 2 are a composite of Kodiak, King Salmon and Cold Bay station records for November to March. An index developed from data for several widely dispersed reporting stations was used in order to reflect historical changes seen in the winter temperatures over the entire region covered in

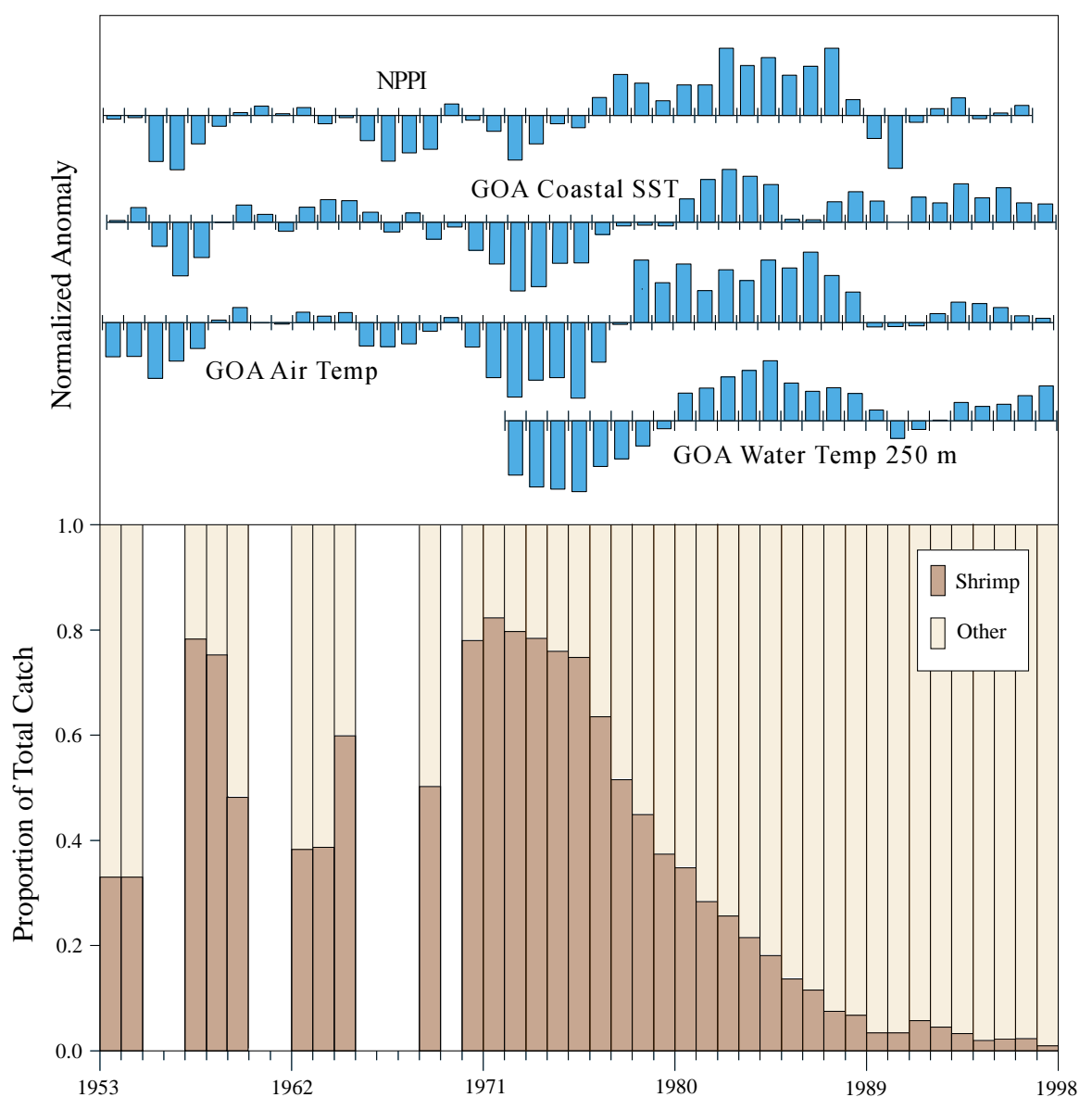

Fig. 2. Changes in proportion of shrimp and other species in shrimp trawl survey catches (3-year running average) in comparison to available climate indices (November through March, normalized) for the Gulf of Alaska, 1953-97. 
this study. The degree of residual winter cooling was thought to be related to population changes of nearshore species. Gulf of Alaska water temperatures at $250 \mathrm{~m}$ depth were obtained from the Institute of Marine Science, Univ. of Alaska, Fairbanks. The location is $59^{\circ} 50.7^{\prime} \mathrm{N}, 149^{\circ} 28.0^{\prime} \mathrm{W}$ and is located within the Alaska Coastal Current. These data span only from 1971 to 1997 , and normalized anomalies in Fig. 2 were calculated from data collected from 15 May to 15 September (autumn/winter data were too infrequent to use for multi-year trends). This index reflects the depth distribution of sampling undertaken in this study; only 66 tows were conducted in water deeper than $250 \mathrm{~m}$. It is also useful for contrasting with SST data, which may or may not reflect heat content of the entire water column.

For illustrative purposes, annual CPUE, percent composition, and climate anomaly data were smoothed using 3-year running averages. All statistics were calculated from unsmoothed data.

Canonical correlation analysis (Dillon and Goldstein, 1984) was used to measure the association between environmental parameters and the relative abundance of three major species groups (pandalid shrimps, gadids including walleye pollock (Theragra chalcogramma) and Pacific cod (Gadus macrocephalus), and pleuronectid flatfish). These groups together represented more than $90 \%$ of catch weights from shrimp surveys. The relation of shrimp abundance and environmental parameters was investigated using Pearson product moment correlations (Snedecor and Cochran, 1967). The hypothesis of no trend or zero correlation was tested using the randomization-permutation correlation test with 10000 permutations (Edgington, 1987).

\section{Results}

Pandalid shrimp have undergone significant population declines in the Gulf of Alaska (GOA) since the late-1970s (Anderson, 1991; Anderson et al., 1997; Orensanz et al., 1998). The area was a major shrimp producer in the eastern Pacific from about 1955 to the end of the 1970s (Anderson and Gaffney, 1977; Orensanz et al., 1998). Shrimp fishing activities concentrated in the numerous bays of Kodiak Island and the adjacent south side of the Alaska Peninsula (Fig. 1). There was also a significant offshore fishery conducted by fleets from Japan and the former Soviet Union in the 1960s through the early-1970s (Ivanov, 1969). The Kodiak Island area was first fished in 1958.
Catches gradually increased until 1971 and then declined (Table 1). All GOA shrimp fisheries declined rapidly after the late-1970s as did abundance as measured by shrimp surveys. Recruitment failure after 1975 (Anderson, 1991) led to a continual population decline until closures were instituted by the ADF\&G in a majority of fishing and all surveyed areas between 1979 and 1985.

CPUE and median "by-tow" $\mathrm{kg} / \mathrm{km}$ were similar $(r=0.94)$ indicating that CPUE was a good measure of abundance. The decrease in Pandalid shrimp coincided with a significant warming trend in the GOA (Fig. 2). Abundance, as measured by standard trawl surveys, declined in the GOA (Table 2). Shrimp abundance, in surveyed areas, averaged $179.3 \mathrm{~kg} / \mathrm{km}$ in the 1972-81 period. In contrast, abundance declined to only $10.1 \mathrm{~kg} / \mathrm{km}$ in the recent $1990-97$ time period (Table 2). Declines occurred in both heavily and lightly fished areas. As an example, Sanak Island gully (approximately $163^{\circ}$ west longitude) was considered an unfished shrimp stock by the ADF\&G (Jackson et al., 1983), yet shrimp surveys showed pandalid abundance declines, from a mean CPUE of $176.9 \mathrm{~kg} / \mathrm{km}$ in $1972-77$ to a mean CPUE of $9.1 \mathrm{~kg} /$ $\mathrm{km}$ in $1978-85$.

In addition to the rapid decline of pandalid shrimp, several non-commercial fish species commonly found in survey catches also declined. This included longsnout prickleback (Lumpenella longirostris) from mean CPUE of $0.9 \mathrm{~kg} / \mathrm{km}(1972-$ 77 ) to $0.5 \mathrm{~kg} / \mathrm{km}$ (1978-97), Pacific spiny lumpsucker (Eumicrotremus orbis) CPUE of $<0.1 \mathrm{~kg} / \mathrm{km}$ (197277) but totally absent from survey catches after 1987 , and capelin (Mallotus villosus) from mean CPUE of $4.4 \mathrm{~kg} / \mathrm{km}(1972-77)$ to $3.4 \mathrm{~kg} / \mathrm{km}$ (1978-97) but had declined to less than $0.05 \mathrm{~kg} / \mathrm{km}$ (1987-97). These incidentally caught species were gradually replaced by several species of pleuronectids and gadids in shrimp survey catches (Anderson and Piatt, 1999). Although pandalid shrimp declined rapidly and had reached minimum abundances by the mid-1980s, the transition to a groundfish dominated community was apparently not completed until the mid-1990s (Fig. $3)$.

All pandalid shrimp species continued to decline after fishing was closed in the nearshore areas (Orensanz et al., 1998). Although adult shrimp populations were relatively high in 1976-79, no strong year-classes were produced by any pandalid species 
TABLE 1. Gulf of Alaska (GOA) Pandalid shrimp trawl landings (tons) in 1958-98. Kodiak Island and Alaska peninsula areas are given separately. * Denotes confidential landing statistics by ADF\&G.

\begin{tabular}{|c|c|c|c|}
\hline Year & Kodiak Island & Alaska Peninsula & GOA \\
\hline 1958 & 14.5 & 0 & 14.5 \\
\hline 1959 & 1298.2 & 0 & 1298.2 \\
\hline 1960 & 1450.6 & 0 & 1450.6 \\
\hline 1961 & 5027.4 & 0 & 5027.4 \\
\hline 1962 & 5739.8 & 0 & 5739.8 \\
\hline 1963 & 4589.7 & 0 & 4589.7 \\
\hline 1964 & 1968.2 & 0 & 1968.2 \\
\hline 1965 & 6270.1 & 0 & 6270.1 \\
\hline 1966 & 10930.4 & 0 & 10930.4 \\
\hline 1967 & 17358.2 & 0 & 7358.2 \\
\hline 1968 & 15634.9 & 2108.5 & 7743.4 \\
\hline 1969 & 18757.8 & 1395.7 & 0153.5 \\
\hline 1970 & 28205.2 & 2396.5 & 0601.7 \\
\hline 1971 & 37264.7 & 2866.7 & 0131.4 \\
\hline 1972 & 26468.4 & 8483.7 & 4952.1 \\
\hline 1973 & 31983.8 & 18416.0 & 0399.8 \\
\hline 1974 & 25494.0 & 21681.9 & 7175.9 \\
\hline 1975 & 26415.7 & 20049.0 & 6464.7 \\
\hline 1976 & 1853.7 & 28282.6 & 30136.3 \\
\hline 1977 & 21188.5 & 32485.1 & 53673.6 \\
\hline 1978 & 11979.2 & 14821.8 & 26801.0 \\
\hline 1979 & 9301.5 & 12182.1 & 21483.6 \\
\hline 1980 & 5834.9 & 5825.7 & 11660.6 \\
\hline 1981 & 12293.0 & 32.2 & 12325.2 \\
\hline 1982 & 8669.3 & 0 & 8669.3 \\
\hline 1983 & 4713.4 & 0 & 4713.4 \\
\hline 1984 & 1260.6 & 0 & 1260.6 \\
\hline 1985 & 1334.9 & 0 & 1334.9 \\
\hline 1986 & 519.8 & 0 & 519.8 \\
\hline 1987 & $*$ & 0 & * \\
\hline 1988 & $*$ & 0 & $*$ \\
\hline 1989 & 0 & 0 & 0 \\
\hline 1990 & 0 & 0 & 0 \\
\hline 1991 & 0 & 0 & 0 \\
\hline 1992 & 0 & 0 & 0 \\
\hline 1993 & 0.8 & 0 & 0.8 \\
\hline 1994 & 0 & 0 & 0 \\
\hline 1995 & 0 & 0 & 0 \\
\hline 1996 & 0 & 0 & 0 \\
\hline 1997 & 0 & 0 & 0 \\
\hline 1998 & 5.4 & 0 & 5.4 \\
\hline
\end{tabular}

during this period (Anderson, 1991). There is evidence that nearshore Pandalids were more vulnerable to the 1977 climate change than species inhabiting deeper water. In particular, humpy shrimp, (Pandalus goniurus), once a significant part of the shrimp biomass in some bays, became nearly extinct. This species averaged $19.3 \mathrm{~kg} / \mathrm{km}$ during the period $1972-$ 81 and declined to very low levels $(<0.1 \mathrm{~kg} / \mathrm{km})$ in
1990-97 surveys (Fig. 4). Humpy shrimp declines continued after closure of the existing commercial fisheries. Pandalus hypsinotus (coonstripe shrimp) is also identified with inshore habitats and a shallow depth range in the GOA. Coonstripe abundance also declined to $>0.1 \mathrm{~kg} / \mathrm{km}$ (Fig. 4) in recent surveys. Like other pandalids, the deep living northern pink shrimp ( $P$. borealis) declined in abundance, but not to the 
near-extinct levels exhibited by the shallow water species (Fig. 4).

Similarly, Pandalopsis dispar (side-stripe shrimp) has declined in abundance from both nearshore and

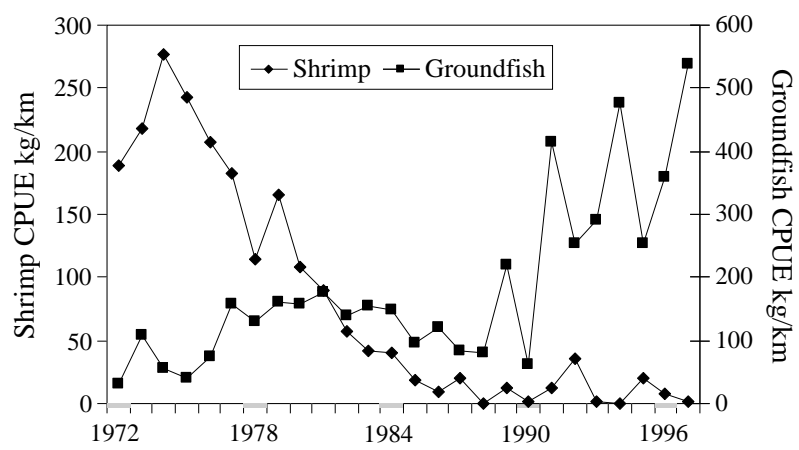

Fig. 3. CPUE $(\mathrm{kg} / \mathrm{km})$ of total pandalid shrimp and groundfish (Pleuronectidae, Pacific cod, and Walleye pollock) in shrimp survey catches, 197297. deep sampling areas. This shrimp has a bathypelagic characteristic and is found at the deepest locations sampled. It is possible that the distribution of this species has shifted to deeper depth intervals, outside sampled areas in response to GOA water column warming. Side-stripes reached near-extinction levels in the sampled areas $>0.1 \mathrm{~kg} / \mathrm{km}$ during recent surveys from higher levels in the early-1970s (Fig. 4).

Canonical correlation analysis of the matrix of relative species abundance in survey catches (matrix $27 \times 3$; Table 3 ) and the set of environment variables (matrix $27 \times 4$; Table 3 ) were correlated at $95 \%$, as indicated by the first canonical variate. The correlation was slightly improved (96\%) when the species were lagged: shrimp and flatfish at one year, gadids at three years (matrix $24 \times 3)$.

The correlations for shrimp abundance relative to water column temperature were significantly different $(P<0.001)$ from zero, indicating that there was a trend

TABLE 2. Indices of pandalid shrimp abundance (total $\mathrm{kg}$ divided by total $\mathrm{km}$ towed) in Gulf of Alaska (GOA) shrimp survey areas, 1972-97. All data reflect standard surveys with the same sampling gear for all years.

\begin{tabular}{|c|c|c|}
\hline Year & Numbers of Tows & Abundance Index \\
\hline 1972 & 161 & 188.7 \\
\hline 1973 & 194 & 217.5 \\
\hline 1974 & 217 & 277.2 \\
\hline 1975 & 557 & 242.2 \\
\hline 1976 & 626 & 207.2 \\
\hline 1977 & 428 & 182.6 \\
\hline 1978 & 419 & 115.1 \\
\hline 1979 & 414 & 165.0 \\
\hline 1980 & 548 & 108.0 \\
\hline 1981 & 775 & 89.2 \\
\hline 1982 & 395 & 56.9 \\
\hline 1983 & 194 & 42.4 \\
\hline 1984 & 334 & 40.0 \\
\hline 1985 & 284 & 19.3 \\
\hline 1986 & 248 & 9.0 \\
\hline 1987 & 228 & 19.6 \\
\hline 1988 & 103 & 0.6 \\
\hline 1989 & 208 & 12.9 \\
\hline 1990 & 158 & 1.0 \\
\hline 1991 & 22 & 12.3 \\
\hline 1992 & 101 & 35.3 \\
\hline 1993 & 22 & 2.1 \\
\hline 1994 & 22 & 0.6 \\
\hline 1995 & 108 & 20.0 \\
\hline 1996 & 22 & 7.5 \\
\hline 1997 & 22 & 2.1 \\
\hline Total & 6812 & \\
\hline
\end{tabular}



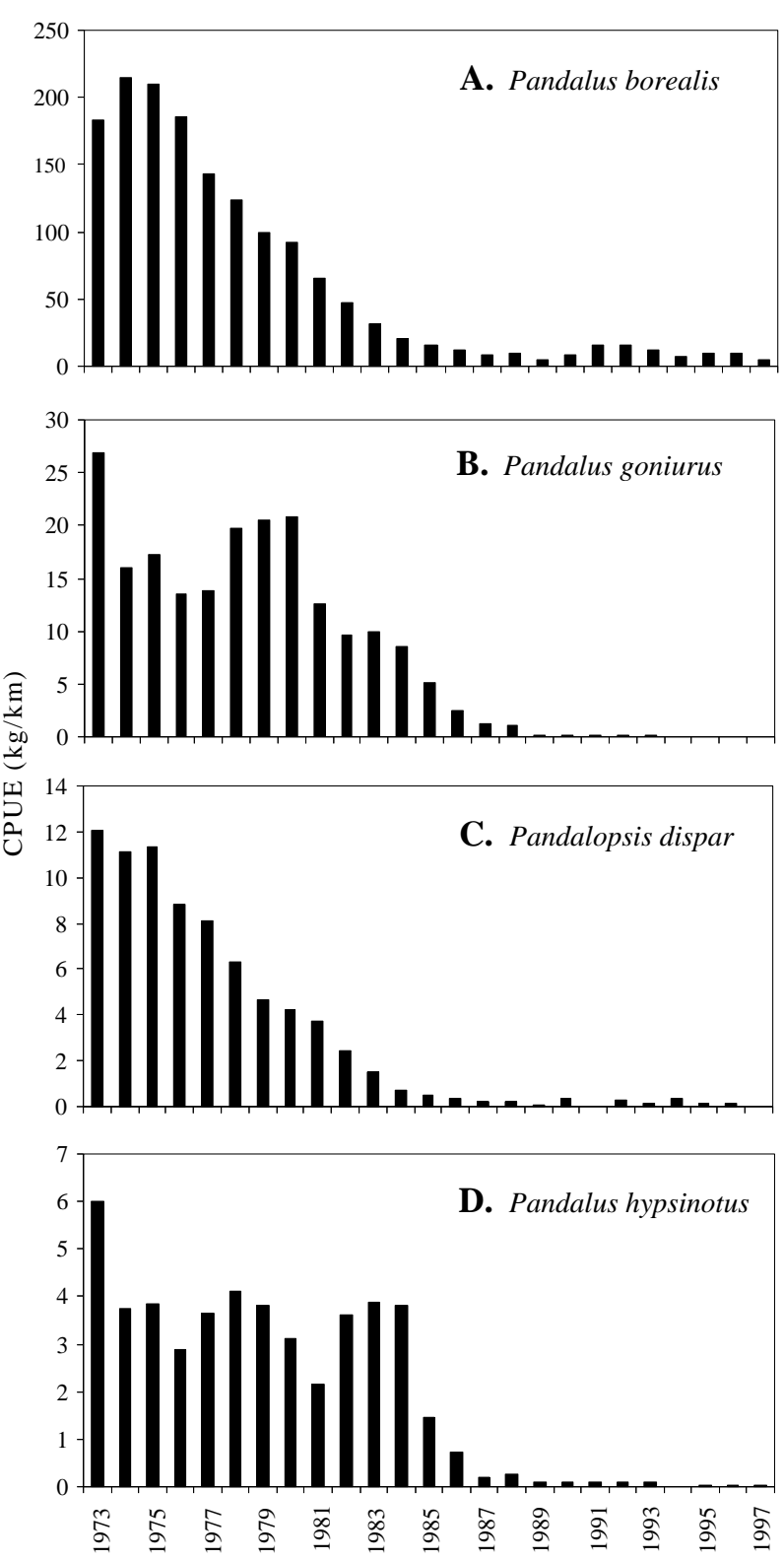

Fig. 4. Relative abundance $(\mathrm{kg} / \mathrm{km})$ of four species of pandalid shrimp in the Gulf of Alaska 1973-97 (3-year running average) from shrimp trawl surveys (A) Pandalus borealis, (B) P. goniurus, (C) Pandalopsis dispar, and (D) Pandalus hypsinotus.

between the variables. The correlation of shrimp CPUE and the water column temperature anomaly (GOA250; Table 3) was $(r=-0.71)$ (Fig. 5A). The correlation between percentage of shrimp in survey catches and the water column temperature anomaly was $(r=-0.72)$ (Fig. 5B).

\section{Discussion}

Data on the most abundant taxa caught in shrimp surveys provide evidence of a climate-driven regime shift in the GOA beginning in the late-1970s where shrimp and some fish species were replaced by a groundfish dominated community. Several pandalid shrimp species declined rapidly in overall abundance and were early indicators of this change. In contrast, other species, comprising mainly groundfish, took several years to completely replace the crustacean community structure in the inshore areas of the GOA. The transition from a cold to a warm regime community structure tended to lag temperature changes and required 15-20 years to complete in some areas of the GOA. However, transition times as short as $2-5$ years have been observed in individual bays (Anderson et al., 1997).

Changes in the thermal regime can have a considerable impact on the abundance of pandalids. In the Gulf of Maine, Dow (1964) found an inverse correlation between sea surface temperatures and shrimp landings. Linkage between the pandalid shrimp decline and water temperatures supports the hypothesis that the GOA ecosystem is regulated to a large degree by bottom-up processes (Francis et al., 1998; McGowan et al., 1998). Pandalid shrimp recruitment is highly dependent on favourable environmental conditions during the embryonic (Nunes and Nishiyama, 1984) and larval phases (Stickney and Perkins, 1981; Shumway et al., 1985). Pandalid shrimp in the GOA have larval stages that last for several months. Dispersal distances and environmental conditions can be highly variable during this period. Variability in the timing of zooplankton production could have a direct effect on recruitment of decapods in the GOA (Paul et al., 1979). The majority of shrimp and crabs in the GOA release larvae in spring or early summer (Orensanz et al., 1998). Two of the strongest shrimp year-classes ever recorded occurred in 1971 and 1975 (Anderson, 1991), when the zooplankton biomass maximum in the Alaska Gyre occurred later than usual (Mackas et al., 1998). Similarly, red king (Paralithodes camshaticus), brown king (Paralithodes brevipes), and Tanner crabs (Chionoecetes bairdi) all exhibited recruitment peaks in the early-1970s (Orensanz et al., 1998). Warming of the water column after 1977 in the GOA caused earlier zooplankton peak abundance (Mackas et al., 1998), which did not favor developing shrimp larvae. Understanding the link 
TABLE 3. Percent of pandalid shrimps, flatfish, and gadids in shrimp survey tows 1971-97. Gulf of Alaska (GOA) environmental variables used in the canonical correlation analysis: (SST10) - sea-surface temperature anomaly smoothed by 10-year running average, (SST3) - sea-surface temperature anomaly smoothed by 3-year running average, (GOA250) temperature anomaly at $250 \mathrm{~m}$, and (GOA Norm) - normalized anomalies of GOA water column temperature.

\begin{tabular}{|c|c|c|c|c|c|c|c|}
\hline Year & $\%$ Shrimp & $\%$ Flatfish & $\%$ Gadid & SST10 & SST3 & GOA250 & GOA Norm. \\
\hline 1971 & 0.88 & 0.01 & 0.10 & -0.34 & -0.41 & -0.43 & -0.59 \\
\hline 1972 & 0.86 & 0.02 & 0.09 & -0.30 & -0.68 & -0.63 & -0.86 \\
\hline 1973 & 0.72 & 0.02 & 0.21 & -0.31 & -0.63 & -0.34 & -0.46 \\
\hline 1974 & 0.80 & 0.02 & 0.13 & -0.30 & -0.40 & -0.73 & -1.00 \\
\hline 1975 & 0.77 & 0.03 & 0.10 & -0.30 & -0.40 & -0.69 & -0.94 \\
\hline 1976 & 0.67 & 0.06 & 0.17 & -0.16 & -0.12 & -0.41 & -0.55 \\
\hline 1977 & 0.49 & 0.08 & 0.35 & -0.05 & -0.03 & -0.08 & -0.10 \\
\hline 1978 & 0.38 & 0.17 & 0.26 & 0.06 & -0.03 & -0.50 & -0.69 \\
\hline 1979 & 0.46 & 0.11 & 0.34 & 0.17 & -0.03 & -0.07 & -0.09 \\
\hline 1980 & 0.29 & 0.11 & 0.30 & 0.19 & 0.23 & 0.37 & 0.50 \\
\hline 1981 & 0.30 & 0.22 & 0.37 & 0.19 & 0.42 & 0.41 & 0.56 \\
\hline 1982 & 0.26 & 0.26 & 0.38 & 0.21 & 0.52 & 0.06 & 0.09 \\
\hline 1983 & 0.20 & 0.22 & 0.49 & 0.26 & 0.45 & 0.65 & 0.88 \\
\hline 1984 & 0.19 & 0.38 & 0.31 & 0.29 & 0.37 & 0.58 & 0.80 \\
\hline 1985 & 0.15 & 0.36 & 0.36 & 0.28 & 0.03 & 0.31 & 0.43 \\
\hline 1986 & 0.06 & 0.24 & 0.55 & 0.19 & 0.02 & 0.07 & 0.09 \\
\hline 1987 & 0.15 & 0.28 & 0.36 & 0.24 & 0.20 & 0.37 & 0.50 \\
\hline 1988 & 0.01 & 0.33 & 0.43 & 0.18 & 0.30 & 0.41 & 0.56 \\
\hline 1989 & 0.05 & 0.36 & 0.50 & 0.17 & 0.21 & -0.08 & -0.11 \\
\hline 1990 & 0.02 & 0.28 & 0.65 & 0.20 & 0.00 & -0.06 & -0.09 \\
\hline 1991 & 0.03 & 0.24 & 0.68 & 0.28 & 0.25 & -0.31 & -0.43 \\
\hline 1992 & 0.11 & 0.37 & 0.40 & 0.22 & 0.19 & 0.15 & 0.20 \\
\hline 1993 & 0.01 & 0.33 & 0.59 & 0.19 & 0.38 & 0.18 & 0.24 \\
\hline 1994 & 0.00 & 0.46 & 0.44 & 0.23 & 0.24 & 0.14 & 0.19 \\
\hline 1995 & 0.07 & 0.34 & 0.51 & 0.22 & 0.34 & 0.05 & 0.07 \\
\hline 1996 & 0.02 & 0.34 & 0.51 & 0.29 & 0.19 & 0.24 & 0.32 \\
\hline 1997 & 0.00 & 0.28 & 0.67 & 0.22 & 0.18 & 0.36 & 0.49 \\
\hline
\end{tabular}
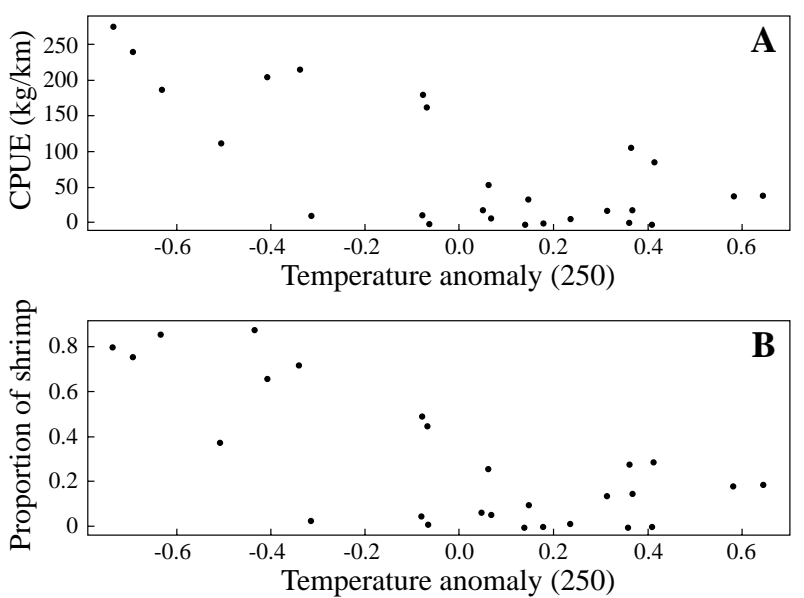

Fig. 5. Comparison of shrimp abundance in survey catches to Gulf of Alaska water column temperature anomaly (250 m) 1971-97 (A) Annual average CPUE of pandalid shrimp in relation to Gulf of Alaska water column temperature anomaly; (B) Annual proportion of shrimp in survey catches compared to Gulf of Alaska water column temperature anomaly. between physical oceanographic processes and pandalid recruitment is important to understanding recruitment variability and developing management strategies for these species. Successful predictive modeling of climate effects will require a comprehensive understanding of the mechanisms involved in the shrimp-environmental relationships described here.

We hypothesize that the near-extinction of $P$. goniurus and $P$. hypsinotus was caused by sustained high winter temperatures after the late-1970s (Royer, 1989). These species are adapted to shallow water conditions and subject to high residual winter cooling during cold years. In contrast, $P$. borealis is found at deeper depths and is buffered from extreme temperature declines or increases in winter.

The results reported in this paper suggest that shrimp react very quickly to warming climate trends and are a useful indicator of impending changes in the ecosystem that require longer time periods to fully 
manifest themselves. It is noteworthy that the GOA and the northeast Pacific are predicted to soon revert to the cold regime (Ingraham et al., 1998). When the climate reverts to colder temperatures the low shrimp population may not rebuild quickly due to its low reproductive potential. In the case of near extinction such as $P$. goniurus, recovery may take a considerable amount of time. The present high biomass of fish in the GOA probably precludes rapid rebuilding of shrimp stocks (Albers and Anderson, 1985). Pandalid shrimp appear to be more useful as indicators of a cold to warm regime change, so it is unlikely that shrimp population changes will reflect any cooling trend for some time. In the canonical correlation, gadids were almost as important as shrimp, perhaps yielding these species as other indicators. Cod may be a useful indicator species when conditions are changing from a warm to a cool climate regime.

Finally, there appear to be some parallels with events in the North Atlantic, where shrimp (Pandalus spp.), capelin (Mallotus villosus) and cod (Gadus morhua) are dominant members of that marine ecosystem. A widespread "gadoid outburst" of the 1960 s was associated with warming temperatures and a shift in the timing and composition of zooplankton biomass (Cushing, 1995). The more recent collapse of northwest Atlantic cod fisheries in the 1980s has been attributed to overfishing but also to recruitment and production failure associated with ocean climate change (deYoung and Rose 1993). In contrast, as groundfish stocks collapsed, the commercial catches of pandalid shrimp, capelin and crabs increased dramatically in the Northwest Atlantic and in West Greenland waters (Koeller 2000; Lilly et al., 2000; Pederson, 1998; Frank et al., 1996; Hvingel and Savard, 1997). Similar to the northeast Pacific the Northwest Atlantic is subject to large decadal climate variations (Hurrell, 1995), which could impact the trophic structure of fished populations.

\section{Acknowledgement}

This work was partially supported by funds from the Exxon Valdez Oil Spill Trustee Council under the Alaska Predator Ecosystem Experiment (APEX) project $99613 \mathrm{~L}$. I also thank my colleagues at the Alaska Department of Fish and Game, particularly James E. Blackburn in Kodiak for his assistance in gaining access to ADF\&G data. Finally, I thank the many scientists and crew who tirelessly collected the data for this project over the last 46 years.

\section{References}

ALBERS, W. D., and P. J. ANDERSON 1985. Diet of the Pacific cod, Gadus macrocephalus, and predation on the Northern pink shrimp, Pandalus borealis, in Pavlof Bay, Alaska. Fish. Bull., U.S., 83: 601-610.

ANDERSON, P. J. 1991. Age, Growth, and mortality of the northern shrimp, Pandalus borealis Kröyer, in Pavlof Bay, Alaska. Fish. Bull., U.S., 89: 541-553.

ANDERSON, P. J., and F. G. GAFFNEY. 1977. Shrimp of the Gulf of Alaska. Alaska Seas and Coasts, 5(3): 13. Available from University of Alaska, Alaska Sea Grant College Program, Fairbanks.

ANDERSON, P. J., J. E. BLACKBURN, and B. A. JOHNSON. 1997. Declines of forage species in the Gulf of Alaska, 1972-95, as indicators of regime shift. In: Proceedings of the International Symposium on the Role of Forage Fishes in Marine Ecosystems November 13-16, 1996, Anchorage, Alaska. B. S. Baxter, (ed.) 1997. University of Alaska Alaska Sea Grant Rep., 9701, p. 531-543.

ANDERSON, P. J., and J. F. PIATT. 1999. Community reorganization in the Gulf of Alaska following ocean climate regime shift. Mar. Ecol. Prog. Ser., 189: 117-123.

CUSHING, D. 1995. Population production and regulation in the sea: a fisheries perspective. Cambridge University Press, Cambridge.

DEYOUNG, B., and G. A. ROSE. 1993. On recruitment and distribution of Atlantic cod (Gadus morhua) off Newfoundland. Can. J. Fish. Aquat. Sci., 50: 27292741 .

DILLON, W. R., and M. GOLDSTEIN. 1984. Multivariate analysis: methods and applications. John Wiley, New York. 587 pp.

DOW, R. L. 1964. A comparison among selected marine species of an association between sea water temperature and relative abundance. ICES J. Cons., 28: 425-431.

DUFRÊNE, M., and P. LEGENDRE. 1997. Species assemblages and indicator species: the need for a flexible asymmetrical approach. Ecological Monographs, 67: 345-366.

EDGINGTON, E. S. 1987. Randomization tests, 2nd edition. Marcel Dekker, New York. 341 pp.

FRANCIS, R.C., S. R. HARE, A. B. HOLLOWED, and W. S. WOOSTER. 1998. Effects of interdecadal climate variability on the oceanic ecosystems of the NE Pacific. Fish. Oceano., 7: 1-21.

FRANK, K. T., J. E. CARSCADDEN, and J. E. SIMON. 1996. Recent excursions of capelin (Mallotus villosus) to the Scotian Shelf and Flemish Cap during anomalous hydrographic conditions. Can. J. Fish. Aquat. Sci., 53: $1473-1486$.

HARRIMAN, E. H. 1910. Harriman Alaska Expedition 1899. Volume I (Narrative) C. H. Merriam (ed.) Smithsonian Inst., 389 p.

HURRELL, J. W. 1995. Decadal trends in the North Atlantic Oscillation: Regional Temperatures and Precipitation. Science, 269: 676-679. 
HVINGEL, C., and L. SAVARD. 1997. Northern shrimp research in the North Atlantic - state of the art and future research strategy. TemaNord, 1997, 592.

INGRAHAM, W. J., C. C. EBBESMEYER, and R. A. HINRICHSEN. 1998. Imminent climate and circulation shift in the northeast Pacific Ocean could have major impact on marine resources. Eos Trans. Amer. Geophys. Union, 79: 199-201.

IVANOV, B. G. 1969. The biology and distribution of the northern shrimp (Pandalus borealis $\mathrm{Kr}$.). In: the Bering Sea and the Gulf of Alaska. FAO Fish. Rep., 57(3): 799-810.

JACKSON, P. B., L. J. WATSON, and S. THOMPSON. 1983. Shrimp Research Report to the Alaska Board of Fisheries March 1983. In: Westward Region Shellfish Report to the Board of Fisheries. Available from ADF\&G, Kodiak, Alaska. p. 310-330.

KOELLER, P. 2000. Relative importance of abiotic and biotic factors to the management of the northern shrimp (Pandalus borealis) fishery on the Scotian Shelf. J. Northw. Atl. Fish. Sci., 27: 21-33.

LILLY, G. R., D. G. PARSONS, and D. W. KULKA. 2000. Was the increase in shrimp biomass on the Northeast Newfoundland Shelf a consequence of a release in predation pressure from cod? J. Northw. Atl. Fish. Sci., 27: 45-61.

MACKAS, D. L., R. GOLDBLATT, and A. G. LEWIS. 1998. Interdecadal variation in developmental timing of Neocalanus plumchrus populations at Ocean Station P in the subarctic North Pacific. Can. J. Fish. Aquat. Sci., 55: $1878-1893$.

MANTUA, N. J., S. R. HARE, Y. ZHANG, J. M. WALLACE, and R. C. FRANCIS. 1997. A Pacific interdecadal climate oscillation with impacts on salmon production. Bull. Am. Meteorol. Soc., 78: 1069-1079.

MCGOWAN, J. A., D. R. CAYAN, and L. M. DORMAN. 1998. Climate-ocean variability and ecosystem response in the Northeast Pacific. Science, 281: 210-217.

NUNES , P., and T. NISHIYAMA. 1984. Effects of temperature on the embryonic development of the northern pink shrimp Pandalus borealis Kroyer. $J$. Shellfish Res., 4: 96-97.

OLSON, T. A., and F. J. BURGESS (eds.). 1967. Pollution and Marine Ecology. J Wiley, New York. 364 p.

OUELLET, P., C. T. TAGGART, and K. T. FRANK. 1995. Early growth, lipid composition, and survival expectations of shrimp Pandalus borealis larvae in the northern Gulf of St. Lawrence. Mar. Ecol. Prog. Ser., 126: $163-175$.

ORENSANZ, J. M., J. ARMSTRONG, D. ARMSTRONG, and R. HILBORN. 1998. Crustacean resources are vulnerable to serial depletion - the multifaceted decline of crab and shrimp fisheries in the greater Gulf of Alaska. Rev. Fish Biol. Fisheries, 8: 117-176.

PAUL, A. J., J. J. PAUL, P. A. SHOEMAKER, and H. M. FEDER. 1979. Prey concentrations and feeding response in laboratory-reared stage-one zoeae of king crab, snow crab, and pink shrimp. Trans. Am. Fish. Soc., 108: $440-443$.

PEDERSEN, S. A. 1998. Distribution and Lipid Composition of Pandalus Shrimp larvae in relation to hydrography in West Greenland waters. J. Northw. Atl. Fish. Sci., 24: 39-60.

PIATT, J. F., and P. J. ANDERSON. 1996. Response of common murres to the Exxon Valdez oil spill and longterm changes in the Gulf of Alaska marine ecosystem. In: Exxon Valdez Oil Spill Symposium Proceedings. Rice, S. D., R. B. Spies, D. A. Wolfe and B. A. Wright (Eds). American Fisheries Society Symposium 18, Bethesda, Maryland, p. 720-737.

POLOVINA, J. J., G. T. MITCHUM, and C. T. EVANS. 1995. Decadal and basin-scale variation in mixed layer depth and the impact on biological production in the central and north pacific, 1960-88. Deep-Sea Res., 42: 1701-1716.

RATHBUN, M. J. 1904. Decapod Crustaceans of the Northwest Coast of North America. In: Rathbun, M .J., H. Richardson, S. J. Holmes, and L. J. Cole 1904. Alaska Volume X Crustaceans of the Harriman Alaska Expedition. Doubleday, Page \& Company, New York, $337 \mathrm{p}$.

RONHOLT, L. L. 1963. Distribution and relative abundance of commercially important pandalid shrimps in the northeastern Pacific Ocean. U. S. Fish. Wildl. Serv. Spec. Sci. Rep. Fish., 449, 28 p.

ROYER, T. C. 1989. Upper ocean temperature variability in the Northeast Pacific Ocean: is it an indicator of global warming? J. Geophys. Res. 94: 18175-18183.

SHUMWAY, S. E., H. C. PERKINS, D. F. SCHICK, and A. P. STICKNEY. 1985. Synopsis of the biological data of the pink shrimp Pandalus borealis (Krøyer, 1938). FAO Fisheries Synopsis, No. 144; NOAA Technical Report, No. NMFS 30, $57 \mathrm{p}$.

STICKNEY, A. P., and H. C. PERKINS. 1981. Observations on the food of the larvae of the northern shrimp, Pandalus borealis Kröyer (Decapoda, Caridea). Crustaceana, 40: 36-49.

SNEDECOR, G. W., and W. G. COCHRAN. 1967. Statistical Methods. Iowa State University Press, Ames, Iowa, $593 \mathrm{p}$

THORSON, G. 1957. Bottom communities. In: Treatise on Marine Ecology and Paleoecology, 1 Ecology, J. W. Hedgepeth, (ed.). Geological Society of America, New York, p. 461-534.

WILES, G. C., R. D. ARRIGO, and G. C. JACOBY. 1998. Gulf of Alaska atmosphere-ocean variability over recent centuries inferred from coastal tree-ring records. Climate Change, 38: 289-306.

WILSON, J. G., and J. E. OVERLAND. 1986. Meteorology. In: The Gulf of Alaska: Physical Environment and Biological Resources, D. W. Hood and S. T. Zimmerman, (eds). U. S. Departments of Commerce and the Interior, Minerals Management Service Publ. OCS Study MMS86-0095, p. 31-54. 